\title{
Upaya Eksekusi Pidana Terhadap Terpidana Kasus Korupsi yang Telah Menjadi Warga Negara Asing (Studi Kasus Atas Nama Djoko Sugiarto Tjandra)
}

\author{
Dewi Shinta*
}

\begin{abstract}
Abstrak
Tindak Pidana Korupsi merupakan salah satu bentuk kejahatan yang masih menjadi masalah yang serius. Rumusan masalah yaitu bagaimana kebenaran upaya hukum terhadap terpidana kasus korupsi yang berada di Negara asing yang sudah menjadi WNA (studi kasus atas nama Djoko Sugiarto Tjandra). Tujuan penelitian untuk menganalisa kebenaran upaya hukum terhadap terpidana kasus korupsi yang berada di Negara asing yang sudah menjadi WNA. Kegunaannya yaitu diharapkan dapat memberikan informasi tentang upaya hukum terhadap terpidana kasus korupsi yang berada di Negara asing yang sudah menjadi WNA. Metode penelitian digunakan adalah metode hukum normatif dan empiris. Hasil Penelitian yaitu pelaku tindak pidana korupsi yang melarikan diri keluar negeri, dalam kasus Bank Bali yakni Djoko Soegiarto Chandra pemerintah dalam mengembalikann ke tanah perlu upaya panjang. Dalam melakukan penilaiaan atas hal-hal tersebut di atas, Negara diminta melakukan 'evidentiary test' atas ketentuan hukum dan bukti-bukti pendukung serta melakukan pemeriksaan silang terhadap ketentuan hukum nasional. Central Authority harus melakukan analisa hukum yang matang serta melengkapi dengan dokumen-dokumen, dan apabila tidak disiapkan sebagai lampiran permohonan MLA dapat berakibat permohonan tersebut tertunda cukup lama atau terjadi bolak-balik sampai dilengkapinya dokumen-dokumen tersebut. Seyogyanya Central Authority adalah instansi yang dapat memberikan prioritas terhadap pengajuan permintaan bantuan hukum timbal balik dari Negara luar maupun pengajuan permintaan bantuan hukum timbal balik yang dimintakan oleh Negara Indonesia sesuai dengan keseriusan dari tindak pidana yang dilakukan dan urgensi dari permohonan tersebut. Kesimpulan yaitu upaya hukum yang dilakukan adalah cacat hukum karena proses peninjauan kembali yang diajukan oleh Jaksa tidak sesuai dengan Pasal 263 Ayat (1) KUHAP.
\end{abstract}

Kata Kunci : Eksekusi Pidana, Korupsi, Warga Negara Asing

\section{Criminal Execution Efforts On Criminal Cases Of Corruption Which Has Been A Foreign Citizen (Case Study Of Djoko Sugiarto Tjandra's Name)}

\begin{abstract}
Corruption is one form of crime that is still a serious problem. The formulation of the problem is how the truth of legal efforts against convicted corruption cases in foreign countries that have become foreigners (case study on behalf of Djoko Sugiarto Tjandra). The purpose
\end{abstract}

* E-mail: dshinta_polhukam@yahoo.co.id 
of this study is to analyze the truth of legal remedies against convicted corruption cases in foreign countries that have become foreigners. Its usefulness is expected to provide information on legal remedies against convicted corruption cases in foreign countries that have become foreigners. The research method used is normative and empirical legal methods. Research results show that the perpetrators of corruption who fled abroad, in the case of Bank Bali namely Djoko Soegiarto Chandra, the government in returning it to the land requires a long effort. In assessing the foregoing, the State is requested to conduct an 'evidentiary test' on the legal provisions and supporting evidence and to cross-examine the provisions of national law. The Central Authority must conduct a thorough legal analysis and complete with the documents, and if not prepared as an attachment to the MLA application may result in the application being delayed long enough or going back and forth until the documents are complete. The Central Authority should be the agency that can give priority to the submission of mutual legal assistance requests from foreign countries as well as submitting mutual legal assistance requests requested by the Indonesian State in accordance with the seriousness of the criminal acts committed and the urgency of the request. The conclusion that the legal remedies carried out are legal defects because the review process submitted by the Prosecutor is not in accordance with Article 263 Paragraph (1) of the Criminal Procedure Code.

Keywords : Criminal Execution, Corruption, Foreign Citizens

\section{Pendahuluan}

Tindak Pidana Korupsi merupakan salah satu bentuk kejahatan yang masih menjadi masalah yang serius. Korupsi di Indonesia terus menunjukan peningkatan dari tahun ke tahun, baik dalam jumlah kasus maupun dalam kerugian Negara. Perbuatan Korupsi di Indonesia masuk dalam kategori kejahatan, karena perbuatan tersebut menyalahkan kewenangan publik yang merugikan Negara atau masyarakat.( Bibit S. Rianto, 2009 : 14)

Korupsi tidak hanya mengakibatkan kerugian keuangan dan perekonomian negara, tetapi juga telah merusak tatanan sistem hukum, menghambat jalannya demokrasi dan pemerintahan yang bersih (good governance), serta merugikan hak-hak sosial ekonomi masyarakat.

Berbagai upaya dilakukan untuk membasmi praktik korupsi seperti membuat Undang-Undang Pemberantasan Tindak Pidana Korupsi, membentuk Pengadilan khusus tindak pidana korupsi dan membentuk suatu badan pemberantasan tindak pidana korupsi yaitu KPK. Namun hal tersebut belum juga dapat membuat efek jera dalam mengurangi tindak pidana korupsi. 
Beberapa hal telah menunjukkan keberhasilan, namun banyak kekurangan yang harus dibenahi. Salah satunya adalah pelaku tindak pidana korupsi yang buron atau melarikan diri ke luar negeri. Pelaku korupsi yang lari dan bersembunyi di luar negeri telah melecehkan hukum Indonesia. Dengan berbagai tipu daya dan rekayasa, mereka berhasil mengelabui aparat penegak hukum untuk menyembunyikan diri besertahasil kejahatannya di luar wilayah Indonesia untuk menghindari jeratan hukum Indonesia. Dalam konteks seperti ini, lembaga ekstradisi diperlukan untuk memulangkan pelaku kejahatan yang kabur ke luar negeri. Ekstradisi sebagaimana diatur dalam Undang-Undang Nomor 1 Tahun 1979 adalah penyerahan pelaku kejahatan yang melarikan diri ke luar negeri atas permintaan negara pemohon kepada negara di mana pelaku kejahatan ini sedang berada. Umumnya permohonan ekstradisi dilakukan jika pelaku kejahatan berkewarganegaraan negara pemohon. Ekstradisi atau penyerahan pelaku kejahatan oleh suatu negara kepada negara lain dapat dilaksanakan berdasarkan perjanjian internasional yang telah ada di antara negara yang bersangkutan, atau berdasarkan kesepakatan timbal baliksebagaimana yang diatur dalam Undang-UndangNomor 1 Tahun 2006.

Meski demikian, upaya ekstradisi mungkin tidak dikabulkan negara tempat pelaku ini berada dengan berbagai pertimbangan. Penolakan terhadap permintaan ekstradisi dapat terjadi jika kejahatan yang disangkakan dianggap sebagai kejahatan politik; sedang dilakukan proses hukum terhadap kejahatan dimaksud di negara termohon; karena terbentur rahasia bank; ancaman pidana dianggap berlebihan; alasan demi kepentingan umum;atau kejahatan dimaksud sebagian atau seluruhnya dilakukan di negara wilayah termohon.

Dalam dua dekade terakhir, masyarakat internasional telah menunjukkan komitmen sangat positif untuk memerangi kejahatan korupsi; karena korupsi dianggap sebagai tantangan multidimensi (HAM, demokrasi, aturan hukum, keamanan manusia/warga negara, pasar, kualitas hidup, dan pembangunan berkelanjutan). Dalam Konvensi PBB tentang Pemberantasan Korupsi (the United Nations Convention Against Corruption/UNCAC 2003), negara-negara didorong untuk saling bekerja sama dalam setiap aspek untuk melawan korupsi. 
Dalam konvensi ini, perang terhadap korupsi merupakan suatu rangkaian proses siklikal yang meliputi pencegahan; kriminalisasi dan penegakan hukum; kerja sama internasional; implementasi; pengembalian aset;danbantuan teknis termasuk pertukaran informasi. Selain upaya diplomasi dan pendekatan legal, upaya ekstradisi untuk memburu koruptor yang bersembunyi di luar negeri juga berhadapan dengan kendala dan beberapa persoalan krusial.

Selain itu keberadaan KPK pada tahun 2002 oleh Presiden Megawati Soekarnoputri didasari makin meningkatnya kasus korupsi dari tahun ketahun sehingga perlu ada suatu Lembaga yang khusus yang menangani kasus korupsi, sedangkan institusi kejaksaan dan kepolisian dinilai tidak mampu menangani dan menangkap koruptor. Jauh sebelumnya, ide awal pembentukan KPK sudah muncul di era Presiden BJ Habibie yang mengeluarkan UU Nomor 28 Tahun 1999 tentang Penyelenggaraan Negara yang bersih dan bebas dari KKN. Habibie kemudian mengawalinya dengan membentuk berbagai komisi atau badan baru seperti KPKPN, KPPU atau lembaga Ombudsman. Presiden berikutnya, Abdurrahman Wahid (Gus Dur) melalui Keppres membentuk Tim Gabungan Pemberantasan Tindak Pidana Korupsi (TGPTPK). Namun, di tengah semangat menggebu-gebu untuk memberantas korupsi melalui suatu judicial review Mahkamah Agung, TGPTPK akhirnya dibubarkan. Sejak itu, Indonesia mengalami kemunduran dalam upaya pemberantasan KKN. Sebagai bentuk semangat pemberantasan korupsi, Megawati mewujudkan. UU Nomor 30 Tahun 2002 Tentang Komisi Pemberantasan Korupsi (KPK).

KPK merupakan lembaga negara yang dibentuk dengan tujuan meningkatkan daya guna dan hasil guna terhadap upaya pemberantasan tindak pidana korupsi. KPK bersifat independen dan bebas dari pengaruh kekuasaan manapun dalam melaksanakan tugas dan wewenangnya. Dalam pelaksanaan tugasnya, KPK berpedoman kepada lima asas, yaitu: kepastian hukum, keterbukaan, akuntabilitas, kepentingan umum, dan proporsionalitas. KPK dalam tugasnya mempunyai empat hal penting yakni melakukan koordinasi, supervisi, penyelidikan, penyidikan, dan penuntutan dengan instansi yang berwenang melakukan pemberantasan tindak pidana korupsi, serta melakukan 
monitor terhadap penyelenggaraan pemerintahan negara. Dalam pelaksanaan tugas dan fungsi KPK tersebut juga menetapkan sistem pelaporan dalam kegiatan pemberantasan tindak pidana korupsi untuk disampaikan secara terbuka dan berkala kepada Presiden, DPR, dan BPK. KPK.

Hambatan bagi upaya ini, antara lain, walaupun berbagai peraturan mengenai tindak pidana korupsi sudah ada tetapi masih adanya orang-orang yang dapat "dibeli" untuk membantu pelaku korupsi. Bahkan ada pihak yang ikut membantu melakukan gangguan atas proses peradilan yang sedang berjalan atas pelaku yang tertangkap dan sedang dalam proses hukum. Berikutnya, upaya memburu koruptor yang kabur ke luar negeri memerlukan langkah sinergis di antara lembaga terkait. Faktanya, sering kali prosedur administratif/birokrasi yang ada sangat berliku sehingga koordinasi sangat lemah. Prosedur administratif yang ruwet telah memberi keleluasaan para koruptor untuk menghindari proses hukum, termasuk kabur ke luar negeri. Masalah lain yang tidak kalah peliknya adalah bagaimana menyeimbangkan kepentingan politik dengan kepentingan hukum, baik di negara pemohon (negara asal pelaku) maupun di negara tempat pelaku kejahatan sedang bersembunyi.

Sejatinya, keberhasilan penegak hukum memanfaatkan lembaga ekstradisi untuk memburu dan menghukum para koruptor yang lari dan bersembunyi di negara lain memiliki makna positif bagi upaya pemberantasan korupsi di Indonesia. Pertama, upaya ini memiliki fungsi penggentaran dan pencegahan, sehingga bagi yang belum melakukan korupsi diharapkan tidak melakukannya. Sementara bagi yang telah jadi tersangka dan atau terpidana kasus korupsi akan berpikir ulang untuk kabur dan bersembunyi ke luar negeri. Kedua, dengan ekstradisi ini, upaya perburuan koruptor yang lari dan bersembunyi di luar negeri akan menjadi bukti keseriusan negara dalam memerangi kejahatan korupsi. Publik akan percaya, mengapresiasi, dan mendukungsetiap langkah penuntasan kasus korupsi, dengan atau tanpa diminta, manakala aparat hukum menunjukkan komitmen dan langkah nyata. Ketiga, upaya ekstradisi para pelaku kejahatan dari negara lain ke Indonesia akan meningkatkan kerja sama internasional dalam penegakan hukum sebagaimana diamanatkan United 
Nations Convention Againts Corruption (UNCAC)/Konvensi internasional anti korupsi. Keempat, upaya ekstradisi terhadap para koruptor yang kabur ke luar negeri akan meningkatkan kapasitas penegak hukum Indonesia dalam mencegah dan memerangi kejahatan korupsi yang bersifat lintas batas. Kelima, upaya ini juga bermakna bagi pengembalian aset negara yang dirampok dan disembunyikan para koruptor.

Berkenaan dengan masalah tersebut, perlu ada kebijakan dalam mencegah dan menangkap pelaku tindak pidana korupsi yang melarikan diri ke luar negeri. Kebijakan tersebut akan efektif apabila ada koordinasi dan kerjasama yang baik antar lembaga penegak hukum baik secara nasional maupun internasional. (Info Singkat Hukum, Vol. IV, Berkas DPR) Salah satu kasus buron pelaku tindak pidana korupsi yang masih menjadi upaya panjang pemerintah untuk mengembalikannya ke tanah air terlihat pada kasus Bank Bali yakni kaburnya atas nama Djoko SoegiartoTjandra, yang diduga telah melarikan diri ke Port Moresby, Papua New Guinea, menggunakan pesawat carteran sejak 10 juni 2009 atau sehari sebelum vonis dibacakan oleh Mahkaman Agung. Wakil Jaksa Agung Darmono menyatakan otoritas Pemerintah PNG telah memberikan kewarganegaraan kepada Djoko Soegiarto Tjandra, sehingga mengalami kesulitan dalam penegakan hukum kepada Djoko SoegiartoTjandra.

Lain halnya dengan beberapa Koruptor yang Tertangkap di Luar Negeri tetapi masih berkewarganegaraan Indonesia. Penangkapan pelaku korupsi di Indonesia tidak selalu berjalan mulus dan tidakmudah. Banyak sekali hambatan mulai dari kongkalikong yang terstruktur rapi, modus menyuap yang membungkam mulut-mulut saksi, bahkan teror yang dilancarkan kepada para penegak keadilan. Selain itu, pilihan kabur ke luar negeri tak jarang menjadi pilihan para koruptor untuk berlindung dari hukuman yang mengejarnya.

Berdasarkan latar belakang masalah yang telah diindentifikasi dan ditegaskan dalam pembatasan masalah maka dapat dirumuskan masalah yaitu : bagaimana kebenaran upaya hukum terhadap terpidana kasus korupsi yang berada di Negara asing yang sudah menjadi WNA (studi kasus atas nama Djoko Sugiarto Tjandra)? 


\section{Pembahasan}

\section{A. Putusan Perkara Eksekusi Pidana Kasus Djoko Soegiarto Tjandra Nomor 12 PK/Pid.Sus/2009}

Alasan Kejaksaan mengajukan Peninjauan Kembali yaitu karena terdapat keadaan baru yang menimbulkan dugaan kuat, bahwa jika keadaan itu sudah diketahui pada waktu sidang masih berlangsung, hasilnya akan berupa putusan pemidanaan. Adapun keadaan baru yang dimaksud dalam memori ini adalah : 1) Putusan Mahkamah Agung RI dalam perkara Peninjauan Kembali TUN Nomor : 21.PK/TUN/2003 tanggal 6 Oktober 2004 yang amarnya: Menolak Permohonan Peninjauan Kembali dari Drs.Setya Novanto dengan salah satu pertimbangannya di hal. 24 menyatakan : "Bahwa PT. Era Giat Prima dalam perjanjian cessie dimaksud tidak sah karena telah dibatalkan dengan SK Ketua BPPN No. SK/423/BPPN/1999; Dengan demikian, apabila putusan Mahkamah Agung RI dalam perkara Peninjauan Kembali Nomor : 59 PK/Pdt/2006 yang menyatakan bahwa cessie antara PT.Bank Bali,Tbk dan PT. Era Giat Prima adalah batal, dan tidak sah, telah diketahui pada saat proses persidangan oleh Judex Juris perkara atas nama terdakwa Djoko Soegiarto Tjandra, maka dalam putusannya unsur melawan hukum dalam perkara tersebut seharusnya terbukti dan dinyatakan bersalah serta dihukum, bukan diputus lepas dari segala tuntutan (onslag van recht verfolging)";

Pada berbagai putusan terdapat pernyataan bahwa sesuatu telah terbukti akan tetapi hal atau keadaan sebagai dasar dan alasan putusan yang dinyatakan telah terbukti itu ternyata telah bertentangan satu dengan yang lain. Bahwa dalam perkara pencairan klaim PT.Bank Bali Tbk yang diajukan ke persidangan sebagai terdakwa antara lain adalah Djoko Soegiarto Tjandra, dan Pande N Lubis yang diajukan secara terpisah (splitzing) namun pertimbangan putusan mengenai unsur turut serta dari ke2 perkara tersebut adalah saling bertentangan. Secara sadar perbuatan masing-masing terdakwa tersebut menjadi sebuah peristiwa yang memenuhi 
semua unsur delik sehingga perbuatan tersebut selesai (voltooid) sebagaimana yang didakwakan; Tetapi kenyataannya putusan dari masingmasing terdakwa tersebut saling berbeda. Seharusnya masing-masing terdakwa yang diajukan oleh penuntut umum dalam persidangan kasus ini telah terbukti melakukan tindak pidana korupsi secara bersama-sama dan para pelakunya dapat dimintai pertanggung-jawaban pidana, karena peristiwa yang mendasari adanya kasus ini adalah satu yaitu Klaim PT.Bank Bali,Tbk kepada Pemerintah atas kewajiban PT.BDNI dalam transaksi SWAP dan money market senilai Rp.904.642.428.369,-.

\section{B. Putusan Mahkamah Konstitusi Nomor: 33/PUU-XIV/2016}

Peninjauan Kembali merupakan upaya hukum yang dapat ditempuh oleh terpidana, orang yang dikenai hukum dalam suatu kasus terhadap satu putusan pengadilan yang telah berkekuatan hukum tetap dalam sistem peradilan Indonesia.

Di tengah polemik yang semakin panas terkait hak pengajuan PK, Mahkamah Konstitusi telah mengabulkan permohonan uji materi Pasal 263 ayat (1) Undang-Undang Nomor 8 Tahun 1981 tentang kitab UndangUndang Hukum Acara Pidana (KUHAP). Dalam putusan itu, MK secara tegas melarang Jaksa Penuntut Umum mengajukan PK atas putusan yang telah berkekuatan hukum tetap. Putusan ini memunculkan pertanyaan dan reaksi dari berbagai pihak. Oleh karena itu sangat penting untuk mendalami makna dari keputusan MK ini.

Namun bisa dilihat apa yang melandasi putusan MK Pasal 263 ayat (1) KUHAP yang berbunyi "Terhadap putusan pengadilan yang telah memperoleh kekuatan hukum tetap, kecuali putusan bebas atau lepas dari segala tuntutan hukum, terpidana atau ahli warisnya dapat mengajukan permintaan peninjauan kembali kepada Mahkamah Agung". MK menegaskan pasal tersebut setidaknya memuat empat landasan pokok.

Pertama, PK hanya diajukan terhadap putusan yang telah berkekuatan hukum tetap. Kedua, PK tidak dapat diajukan terhadap putusan bebas atau 
lepas dari segala tuntutan hukum. Ketiga, permohonan PK hanya dapat diajukan oleh terpidana atau ahli warisnya. Keempat, PK hanya dapat diajukan terhadap putusan pemidanaan. Dari sini sudah jelas sebenarnya upaya hukum PK merupakan semata-mata untuk menegakkan hak konstitusi terpidana yang dilindungi hukum.

Hakim Konstitusi Aswanto juga berpendapat bahwa, "Perlu diketahui bahwa esensi landasan filosofis lembaga PK ini ditujukan untuk kepentingan terpidana atau ahli warisnya sebagai bentuk perlindungan Hak Asasi Manusia. Bukan kepentingan negara atau korban. Kalau esensi ini dihapus tentu lembaga PK akan kehilangan maknanya dan tidak berarti,” ujarnya. "Jika Jaksa masih tetap diberikan hak mengajukan PK, padahal sudah diberi hak mengajukan upaya hukum biasa (banding dan kasasi), justru menimbulkan ketidakpastian hukum sekaligus tidak berkeadilan..

Bila ditelisik lebih jauh, makna di balik putusan MK tersebut dari landasan filosofis hukum tentu mempunyai alasan yang logis. Seperti yang sampaikan oleh Muhammad Ainul Syamsu, seorang praktisi hukum, yang turut mengapresiasi putusan MK. "Karena putusan ini sekaligus mengakhiri perdebatan boleh atau tidaknya Jaksa Penuntut Umum mengajukan PK terhadap putusan inkracht. Sebab, secara filosofis pengajuan PK sejak dari awal ditujukan melindungi kepentingan terpidana atau ahli warisnya dan bukan kepentingan negara yang diwakili oleh lembaga kejaksaan, korban, atau pihak lain.

Selama ini penerapan Pasal 263 ayat (1) KUHAP ditafsirkan berbedabeda oleh aparat penegak hukum. "Makanya, MK memandang perlu mengakhiri silang pendapat tersebut dengan menegaskan bahwa Jaksa/Penuntut Umum tidak boleh mengajukan PK,"

Dari sini bisa dilihat dasar MK mengeluarkan putusan tersebut. Bila ditelusuri poin per poin makna di balik Pasal 263 tersebut, tentunya akan menemukan maksud di balik putusan MK yakni:

Pertama, PK hanya diajukan terhadap putusan yang telah berkekuatan hukum tetap. Yang dimaksud Keputusan yang berkekuatan hukum tetap 
adalah keputusan yang dikeluarkan oleh hakim pengadilan terhadap suatu perkara/kasus di mana tidak dimungkinkan lagi melakukan upaya hukum terhadap keputusan tersebut disinilah PK boleh diajukan.

Kedua, PK tidak dapat diajukan terhadap putusan bebas atau lepas dari segala tuntutan hukum, dari sini bisa dilihat bahwa PK hanya bisa diajukan bagi para terpidana yang dipenjara.

Ketiga, permohonan PK hanya dapat diajukan oleh terpidana atau ahli warisnya. Inipun sangat jelas yang tidak memerlukan penjabaran lebih jauh.

Keempat, PK hanya dapat diajukan terhadap putusan pemidanaan. Pada poin yang empat ini pun telah sangat sangat jelas bahwa kasus-kasus pidana seperti korupsi, pembunuhan dan sebagainya termasuk area PK yang boleh di ajukan oleh terpidana atau ahli warisnya.

Polemik pengajuan Peninjauan Kembali oleh Jaksa/Penuntut Umum merupakan isu yang sudah diperdebatkan sejak lama. Isu ini sudah diperdebatkan oleh kalangan akademisi sampai praktisi hukum. Asal mula perdebatan ini berawal dari pengajuan PK oleh Jaksa/PU pada kasus Muchtar Pakpahan (No. 55PK/Pid/1996), sampai pada kasus lainnya seperti kasus RAM Gulumal (No. 03PK/Pid/2001), Setyawati (No. 15PK/Pid/2006), dr. Eddy Linus dkk (No. 54PK/Pid/2006), Syahril Sabirin (No. No. 07 PK/Pidsus/2009), Polycarpus (No. 109PK/Pid/2007) dan Djoko S Tjandra (No. 12PK/Pidsus/2009). Tentunya sudah banyak dijelaskan kalau langkah Kejaksaan ketika itu menjadi yurisprudensi terhadap pengajuan PK oleh Jaksa/PU di masa selanjutnya, walaupun sudah jelasjelas melanggar Pasal 263 pasal (1) KUHAP. Dan di Era Reformasi, pada 12 Mei 2016, Mahkamah Konstitusi menegaskan tindakan Jaksa/PUmengajukan PK tersebut inkonstitusional.

Pelanggaran Kejaksaan atas Pasal 263 ayat (1) KUHAP ini sudah mengalami perjalanan panjang. Dari perjalanan panjang itu sudah banyak hak terpidana yang dilanggar. Pertama, PK hanya dapat diajukan terhadap keputusan yang telah memperoleh kekuatan hukum tetap. 
Kedua, karena PK ini sejatinya hanya hak terpidana atau ahli warisnya. Ketiga, karena seharusnya PK tidak dapat diajukan atas keputusan bebas atau lepas dari segala tuntutan hukum. Keempat, PK ini hanya dapat diajukan terhadap putusan pemidanaan. Sudah banyak juga upaya untuk membenahi polemik ini. Mulai dari pengajuan uji materi Pasal 268 ayat (3) KUHAP yang membatasi pengajuan PK hanya satu kali yang dimohonkan mantan ketua KPK Antasari Azhar. Sampai pengajuan uji materi Pasal 263 ayat (1) KUHAP oleh Anna Boentaran. Namun setelah MK membatalkan Pasal 268 ayat (3) KUHAP, dan menyatakan PK bisa diajukan lebih dari satu kali, Mahkamah Agung mengeluarkan Surat Edaran MA (SEMA) Nomor 7 Tahun 2014, yang menyatakan PK hanya bisa satu kali. Dengan dikeluarkannya SEMA ini dengan jelas MA telah melanggar putusan MK yang menjamin hak konstitusi terpidana atau ahliwarisnya. Dan sampai sekarang SEMA tersebut masih berlaku dan membatasi hak dari terpidana yang menghadapi penuntut umum.

Selanjutnya keputusan MK kembali tidak dihormati setelah keluarnya putusan atas Pasal 263 ayat (1) KUHAP. Putusan ini sebenarnya bukan menentukan pasal tersebut sesuai atau tidak sesuai konstitusi, tapi hanya mempertegas tafsiran. Namun walau MK sudah mempertegas Jaksa Penuntut Umum dilarang mengajukan PK, Kejaksaan Agung tetap ingin mengeksekusi peradilan PK oleh Jaksa Penuntut Umumsebelum keputusan MK tersebut keluar. Tindakan Jaksa ini dipandang sebagai ketidakpatuhan Jaksa terhadap putusan MK, yang artinya ketidakpatuhan terhadap konstitusi.

Perdebatan berlanjut pada implikasi putusan MK atas Pasal 263 ayat (1) KUHAP ini. Apakah berlaku retroaktif (berlaku surut) atau prospektif (berlaku ke depan). Kalau berlaku retroaktif maka peradilan PK oleh sebelum-sebelum keluarnya putusan MK sudah seharusnya batal demi hukum. Namun jika pun putusan MK tersebut berlaku prospektif, maka sebenarnya putusan peradilan PK oleh Jaksa sebelumnya tetap melukai rasa keadilan, karena dasar hukumnya sudah dibatalkan oleh MK. Dan sudah 
seharusnya putusan peradilan PK yang diajukan oleh Jaksa tersebut dibatalkan oleh peradilan lain.

Kemudian banyak ahli hukum yang mencoba menawarkan solusi atas peradilan PK oleh Jaksa sebelum putusan MK ini. Dari yang mengatakan kalau putusan MK ini bukan merupakan norma baru, sehingga seharusnya juga berlaku ke belakang. Ada juga yang mengatakan berlaku prospektif. Sampai untuk membatalkan putusan PK oleh Jaksa sebelum putusan MK dikeluarkan harus dengan putusan peradilan lagi. Keputusan peradilan yang dimaksud adalah pengajuan PK atas peradilan PK yang diajukan Jaksa sebelumnya. Karena sejatinya PK hanya hak dari terpidana atau ahli warisnya.

Dapat disimpulkan bahwa Putusan MK Nomor 33/PUU-XIV/2016 menegaskan kembali Pasal 263 ayat (1) KUHAP bahwa pasal tersebut konstitusional sepanjang tidak dimaknai lain selain dimaknai PK hanya dapat diajukan oleh terpidana atau ahli warisnya dan tidak boleh diajukan terhadap putusan bebas atau lepas. Apabila melihat kasus-kasus PK oleh Jaksa/PU di atas, dapat dipastikan Permohonan dan Putusan PK tersebut inkonstitusional. Jika permohonan dan putusan itu inkonstitusional, maka putusan tersebut non-executable/tidak bisa dieksekusi karena tidak sesuai dengan undang-undang dan dinilai sangat merugikan salah satu pihak. Dengan demikian, putusan tersebut dengan sendirinya tidak dapat dieksekusi atau dilaksanakan oleh Jaksa sebagai eksekutor putusan pengadilan. Jadi seharusnya pihak Kejaksaan dapat mengakui kesalahan yang telah dilakukan dalam mengajukan permohonan PK itu. Karena dasar hukum yang digunakan tidak dapat membenarkan adanya permohonan PK oleh Jaksa/PU apalagi dilakukan pada putusan bebas dan lepas dari segala tuntutan hukum.

Dalam uraian diatas memperlihatkan uraian diatas permasalahan hukum kasus Bank Bali Tbk dimana Pande N Lubis dipidana sedangkan Djoko Tjandra lepas dari segala tuntutan hokum dan kemudian yang bersangkutan dipidana melalui putusan PK, padahal pasal 263 dan pasal 266 
KUHAP tidak termasuk yang dapat diajukan PK, hal ini sudah terjawab bahwa pengajuan PK oleh jaksa tidak berdasar. Djoko S Tjandra telah menunjukan kepada negara dimana ia berada (supaya tidak di ekstradisi) karena tidak ada dasar hokum untuk mempidana orang melalui PK bagi putusan bebas dan lepas dari segala tuntutan hukum.

Maka untuk menebus kesalahan yang dilakukan oleh Jaksa/JPU tersebut, seharusnya Kejaksaan segera mengajukan rehabilitasi kepada Presiden RI terhadap Muchtar Pakpahan (Putusan No. 55PK/Pid/1996), RAM Gulumal (Putusan No. 03PK/Pid/2001), Setyawati (Putusan No. 15PK/Pid/2006), dr. Eddy Linus dkk (Putusan No. 54PK/Pid/2006), Syahril Sabirin (Putusan No. No. 07 PK/Pidsus/2009), Polycarpus (Putusan No. 109PK/Pid/2007) dan mengajukan permohonan pemberian Grasi kepada Djoko S Tjandra (Putusan No. 12PK/Pidsus/2009). Hal itu karena, hak-hak terpidana itu harus diberikan sesuai dengan hukum yang berlaku di Indonesia.

\section{Pelaksanan Putusan Pidana terhadap Terpidana Kasus Korupsi yang berada di Luar Negeri dan Telah menjadi warga Negara Asing}

Kejahatan atau tindak pidana korupsi dapat kita kategorikan sebagai kejahatan lintas Negara (Transnasional Crime) apabila kejatahan tersebut memenuhi hal-hal sebagai berikut:

1. Tindak Pidana Korupsi atau nisa terjadi dimana saja pada semua Negara;

2. Untuk menghindari proses hokum yang dilakukan di negaranya, para pelaku tinda pidana korupsi dimungkinkan bersembunyi ke Negara lain;

3. Untuk menyelamatkan hasil kejahatan/tindak pidana korupsi, para pelaku sering menyembunyikan asetnya di Negara lain;

4. Untuk melakukan pengejaran, penangkapan pelaku serta aset hasil tindak pidana korupsi di luar negeri diperlukan kerjasama bantuan hukum timbal balik antar negara.

Berdasarkan Undang-Undang Nomor 1 Tahun 1979 Tentang Ekstradisi, yang dimaksud dengan Ekstradisi adalah penyerahan oleh suatu negara kepada 
negara yang meminta penyerahan seseorang yang disangka atau dipidana karena melakukan suatu kejahatan di luar wilayah negara yang menyerahkan dan di dalam yurisdiksi wilayah negara yang meminta penyerahan tersebut karena berwenang untuk mengadili dan memidananya.

Permintaan dan Penerimaan Ekstradisi dapat dilakukan berdasarkan suatu perjanjian, tetapi dalam hal belum ada perjanjian maka permintaan dan penerimaan bantuan dapat dilakukan atas dasar hubungan baik berdasarkan prinsip resiprositas (timbal balik), "hubungan baik" disini adalah hubungan bersahabat dengan berpedoman pada kepentingan nasional dan berdasarkan kepada prinsip-prinsip persamaan kedudukan, saling menguntungkan, dan memperhatikan, baik hukum nasional maupun hukum internasional yang berlaku. Pemerintah Republik Indonesia telah membuat Perjanjian Ekstradisi dengan beberapa negara. Salah satunya dengan Negara PNG, dalam tulisan ini telah diketahui bahwa terpidana atas nama DJOKO Chandra telah melarikan diri ke Negara PNG

Menteri Hukum dan Hak Asasi Manusia merupakan Central Authority atau otoritas pusat dalam hal pengajuan dan penanganan permintaan bantuan timbal balik dalam masalah pidana serta permintaan ekstradisi, artinya bahwa dalam pengajuan permohonan ekstradisi ataupun MLA dalam suatu kasus oleh Pemerintah RI kepada suatu negara dibuat / dilakukan oleh Kementerian Hukum dan HAM selaku Central Authority. Undang-Undang Nomor 1 Tahun 1979 merupakan dasar hukum bagi Pemerintah Republik Indonesia dalam meminta ekstradisi atau penyerahan oleh suatu negara yang meminta penyerahan seorang yang disangka/dipidana, karena melakukan suatu kejahatan di luar wilayah negara yang menyerahkan karena berwenang untuk mengadili dan menghukumnya. Undang-Undang ini juga memberikan dasar hukum bagi pembuatan perjanjian dengan negara-negara asing maupun untuk menyerahkan seseorang tanpa adanya perjanjian. Dari uraian di atas memberikan pemahaman bahwa upaya untuk membawa kembali seorang pelaku tindak pidana di Indonesia untuk dapat diproses dan dimintai pertanggungjawaban pidana menurut sistem hukum Indonesia adalah melalui mekanisme "Ekstradisi". 
Namun demikian apabila pemerintah negara setempat bisa membuktikan bahwa pelaku tersebut telah melakukan pelanggaran hukum keimigrasian maka pelaku tindak pidana tersebut dapat diserahkan kepada Pemerintah RI melalui mekanisme "DEPORTASI".

Undang-Undang Nomor 1 Tahun 2006 tentang Bantuan Timbal Balik dalam Masalah Pidana juga merupakan dasar hukum bagi Pemerintah Republik Indonesia untuk mengajukan dan menerima permintaan MLA. Masih diperlukan Central Authority dalam mekanisme bantuan timbal balik dan ekstradisi karena Secara umum fungsi Central Authority diperlukan karena adanya perbedaan sistem hukum nasional negara-negara dalam proses penegakan hukum. Di dalam praktek sering terjadi, suatu negara yang telah memiliki otoritas berkeinginan untuk mengajukan suatu permintaan bantuan timbal balik, tetapi tidak mengetahui kepada otoritas mana permintaan akan diteruskan dan siapa yang berwenang pada negara yang akan dimintakan bantuannya. Ruang lingkup operasional suatu Central Authority, sangat bersifat teknis yuridis baik materill maupun formil. Aspek pidana materiil dalam kegiatan operasional Central Authority antara lain adalah memformulasikan dan melakukan analisis prinsipprinsip double criminality, speciality, kepentingan umum, kepentingan negara, dan delik-delik politik. Sedangkan aspek pidana formil yang harus diformulasikan dan dianalisa, antara lain adalah penguasaan hukum acara pidana dan perdata baik di Indonesia ataupun di Negara lain yang terkait, mengingat kekuatan pembuktian dokumendokumen yang diperlukan dalam proses MLA maupun Ekstradisi sangat ditentukan oleh proses yang dilaksanakan oleh Central Authority. Begitu pula proses Ekstradisi maupun MLA seringkali membutuhkan dan mengakibatkan proses pemeriksaan pengadilan (hearing), yang harus dipahami secara mendalam oleh Central Authority.

Dalam melakukan penilaiaan atas hal-hal tersebut di atas, Negara Diminta akan melakukan 'evidentiary test' atas ketentuan hukum dan bukti-bukti pendukung serta melakukan pemeriksaan silang terhadap ketentuan hukum nasionalnya. Dalam hal ini tentu saja Central Authority harus melakukan analisa hukum yang matang serta melengkapi dengan dokumen-dokumen, dan apabila 
tidak disiapkan sebagai lampiran permohonan MLA dapat berakibat permohonan tersebut tertunda cukup lama atau terjadi bolak-balik sampai dilengkapinya dokumen-dokumen tersebut. Seyogyanya Central Authority adalah instansi yang dapat memberikan prioritas terhadap pengajuan permintaan bantuan hukum timbal balik dari Negara luar maupun pengajuan permintaan bantuan hukum timbal balik yang dimintakan oleh Negara Indonesia sesuai dengan keseriusan dari tindak pidana yang dilakukan dan urgensi dari permohonan tersebut. Selain itu Central Authority sebaiknya diletakan pada instansi yang masuk dalam ICJS (Integrated Criminal Justice System) sehingga urgensi permintaan ekstradisi maupun bantuan hukum timbal balik dalam masalah pidana yang dibutuhkan dalam proses penyidikan untuk kepentingan pembuktian termasuk pelacakan dan perampasan asset yang dibawa kabur ke negara lain dapat segera direspon dengan cara yang lebih efektif karena berada pada instansi yang memang mempunyai hubungan, kapasitas dan kewenangan untuk melakukan penyidikan, penuntutan, dan eksekusi.

Memperhatikan uraian tersebut diatas dan sudah adanya putusan PK Nomor 12/Pid.Sus/2009 a.n Djoko Soegiarto Tjandra, pemerintah RI telah membuat perjanjian ekstradisi (Extradition Treaty) dengan pemerintah Papua Nugini sejak 17 Juni 2013.yang disah melalui Undang undang Nomor 6 Tahun 2015. Atas dasar itu Pemerintah RI melalui Menkumham selaku Lembaga central Authority dan Jaksa Agung selaku Lembaga penegak hukum yang melaksanakan eksekusi putusan PK dapat mengajukan ekstradisi terpidana kasus korupsi a.n Djoko Soegiarto Tjandra, yang berganti nama Joe Chan kepada pemerintah Papua Nugini. Hal ini harus segera dilakukan mengingat tahun ini 2018 diperoleh informasi terbaru dari Papua Nugini bahwa Komisi Ombudsman Papua Nugini telah mengumunkan hasil investigasi yang menyatakan kewarganegaraan a.n Djoko Soegiarto Tjandra, yang berganti nama Joe Chan melanggar hukum sehingga kewarganegaraannya harus dicabut. Komisi Ombudsman menemukan 18 pelanggaran yang dilakukan saat itu oleh Kepala Imigrasi (Mataio Rabura) serta Menteri Luar Negeri dan Imigrasi (Ano Pala), yang menyebabkan pemberian status kewarganegaraan Djoko Soegiarto Tjandra, bertentangan 
dengan Undang-Undang Kewarganegaraan Papua Nugini. Sebagai respon terhadap temuan Komisi Ombudsman Papua Nugini dimana hasil investigasi dinyatakan kewarganegaraan pengusaha Djoko Chandra alias Joe Chan melanggar hukum sehingga harus dicabut, maka Pemerintah Papua Nugini melalui Perdana Menteri Peter O’Neill dihadapan Parlemen Papua Nugini menyatakan akan mencabut paspor yang dikeluarkan secara illegal kepada terpidana buron dari Indonesia atas nama Djoko Soegiarto Tjandra, alias Joe Chan. Selain itu, Perdana Menteri akan memecat dan mempidanakan orangorang yang terlibat dalam pemrosesan paspor illegal Djoko Soegiarto Tjandra, Dengan demikian, Pemerintah Indonesia memiliki dasar yuridis yang kuat untuk dapat melakukan upaya eksekusi pidana terhadap Djoko Soegiarto Tjandra, melalui mekanisme Ekstradisi berdasarkan Undang-Undang Nomor Nomor 6 Tahun 2015 tentang Pengesahan Perjanjian Ekstradisi Antara Republik Indonesia dan Papua Nugini. Realisasi upaya paksa tersebut dengan mempersiapkan regulasi teknis impelementasi ekstradisi sambil tetap memperhatikan perkembangan politik hukum dalam negeri Papua Nugini terkait proses pencabutan paspor dan kewarganegaraan Djoko Soegiarto Tjandra, alias Joe Chan.

\section{Penutup}

\section{A. Kesimpulan}

Bahwa Putusan Mahkamah Agung RI Nomor : 1688 K/Pid/2000 tanggal 28 Juni 2001 atas nama terdakwa Djoko Soegiarto Tjandra menyatakan perbuatan terdakwa Djoko Soegiarto Tjandra terbukti (sebagaimana dakwaan primer), tetapi perbuatan itu tidak merupakan perbuatan pidana sehingga terdakwa Djoko Soegiarto Tjandra dilepas dari segala tuntutan hukum (onslag van rechtverfolging). Namun Jaksa Penuntut Umum mengajukan Peninjauan Kembali dengan putusan Peninjauan Kembali Mahkamah Agung RI Nomor 12.PK/PID./2009 tanggal 11 Juni 2009 yang Menjatuhkan pidana kepada terdakwa Djoko Soegiarto Tjandra pidana penjara selama 2 (dua) tahun. Atas 
dasar tersebut Penulis menyimpulkan bahwa pidana penjara selama 2 (dua) tahun terhadap terdapat Djoko Soegiarto Tjandra cacat hukum karena proses Peninjauan Kembali yang diajukan oleh Kejaksaan tidak sesuai dengan pasal 263 ayat (1) KUHAP yaitu yang diberihak untuk mengajukan PK hanya kepada terpidana atau ahli warisnyas edangkan Jaksa tidak termasuk dalam keluarga. Sedangkan pihak kejaksaan/penegak hukum lainnya dalam proses pengajuan PK mengacu pada pasal 49 Undang-Undang Nomor 5 Tahun 1986 jo UndangUndang Nomor 9 Tahun 2004 Tentang Peradilan Tata Usaha Negara, pasal 35 huruf c Undang-Undang Nomor 16 Tahun 2004 Tentang Kejaksaan dan pasal 21 Undang-Undang Nomor 14 Tahun 1970 Tentang Ketentuan-Ketentuan Pokok Kekuasaan Kehakiman dimana dalam penjelasannya antara lain menyatakan bahwa demi kepentingan umum para pihak boleh mengajukan PK yang dimaksud para pihak adalah Jaksa, Hakim atau Terpidana.

\section{B. Saran}

Perlu merevisi peraturan perundangan yang bertentangan dengan Pasal 263 (2) KUHAP terkait Pengajuan Peninjauan Kembali antara lain pada pasal 49 Undang-Undang Nomor 5 Tahun 1986 jo Undang-Undang Nomor 9 Tahun 2004 Tentang Peradilan Tata Usaha Negara, pada pasal 35 huruf c UndangUndangNomor 16 Tahun 2004 Tenrtang Kejaksaan dan pada pasal 21 UndangUndangNomor 14 Tahun 1970 Tentang Ketentuan-Ketentuan Pokok Kekuasaan Kehakiman Dalam hal pelaksanaan upaya Eksekusi atas putusan putusan Peninjauan Kembali Mahkamah Agung RI Nomor 12.PK/PID./2009 tanggal 11 Juni 2009 yang memuat amar putusan antara lain Menjatuhkan pidana kepadat erdakwa Djoko Soegiarto Tjandra pidana penjara selama 2 (dua) tahun, sehingga putusan MA tersebut batal demi hukum karena bertentangan dengan ketentuan perundang-undangan. 


\section{Daftar Pustaka}

Chazawi, Adam. Pelajaran Hukum Pidana Bagian I. Jakarta. Raja Grafindo Persada. 2002.

Evi Hartati. Tindak Pidana Korupsi. Semarang, Sinar Grafika, 2012

Gautama, Sudargo. Pengertian tentang Negara Hukum, Bandung. Alumni, 1983.

Marzuki, Peter Mahmud. Penelitian Hukum, Jakarta. Kencana, 2005

Muladi dan Barda Nawawi Arief. Teori-Teori dan Kebijakan Pidana. Bandung, Alumni, 2005.

P.A.F Lamintang, Dasar-Dasar Hukum Pidana Indonesia, Bandung. Citra Aditya Bakti, 1997.

Poerwardaminta, WJS. Kamus Besar Bahasa Indonesia. Balai Bahasa. Jakarta. 1986.

Rianto, Bibit S, Korupsi Go To Hell!! Mengupas Anatomi Korupsi di Indonesia, Jakarta, Hikmah, 2009.

Soekanto, Soerjono. Faktor-Faktor yang Mempengaruhi Penegakan Hukum. Raja Grafindo Persada. Jakarta. 2007.

Soekanto, Soerjono. Penelitian Hukum Normatif: Suatu Tinjauan Singkat, Jakarta: PT. RadjaGrafindo Persada, 2007

Sastrawidjaja, Sofjan. Hukum Pidana, Bandung. Armico. 1995.

Tongat. Dasar-Dasar Hukum Pidana Indonesia Dalam Perspektif Pembaharuan. Malang. UMM Press. 2009

Tutik, Titik Triwulan. Pokok-pokok Hukum Tata Negara Indonesia Pasca Amandemen UUD 1945. Cerdas Pustaka

Indonesia. Undang-Undang Nomor 1 Tahun 1979 tentang Ekstradisi. . Undang-Undang Nomor 31 Tahun 1999 tentang Pemberatasan Tindak Pidana Korupsi

Info Singkat Hukum, Vol. IV, NO. 12/II/P3DI/Juni/2012, Pencegahan dan Penangkapan Pelaku Tindak Pidana Korupsi yang Melarikan Diri ke Luar negeri, Novianto M. Hantoro, berkas.dpr.go.id. diakses tanggal 10 Januari 2018 